\title{
Integration of EST-SSR markers of Medicago truncatula to intraspecific linkage map of lentil and identification of QTL conferring resistance to ascochyta blight at seedling and pod stages
}

Dorin Gupta ${ }^{1}$, Paul W J Taylor ${ }^{2}$, PrabhpreetInder ${ }^{2}$, Richard Oliver ${ }^{3}$, P N Mathur ${ }^{4}$, Ashutosh Sarker ${ }^{5}$, Rebecca Ford ${ }^{2}$

${ }^{1}$ Department of Crop Improvement, CSK Himachal Pradesh Agricultural University,Palampur, Himachal Pradesh, India; ${ }^{2}$ Biomarka/Centre for Plant Health, Melbourne School of Land and Environment, University of Melbourne, Victoria 3010, Australia; ${ }^{3}$ Department of Agriculture and Environment, School of Science, Curtin University of Technology, Perth, Western Australia; ${ }^{4}$ Bioversity International, New Delhi, India; ${ }^{5}$ International Center for Agricultural Research in Dry Areas (ICARDA), New Delhi, India

\section{Summary:}

Microsatellite markers have been extensively utilised in the leguminosae for genome mapping and identifying major loci governing traits of interest for eventual marker assisted selection (MAS). The lack of available lentil-specific microsatellite sequences instigated the mining and transfer of EST-SSR/SSR sequences from the model genome Medicago truancatula, to enrich the existing intraspecific lentil linkage map. A total of 196 markers, including 15 Mt EST-SSR/SSR, were mapped using a population of $94 \mathrm{~F}_{5}$ RIL produced from the cross $\mathrm{cv}$. Northfield (ILL5588) $\mathrm{x}$ cv. Digger (ILL5722) and clustered into 11 linkage groups (LG) covering $1156.4 \mathrm{cM}$. Subsequently, the size and effects of QTL conditioning Ascochyta lentis resistance at seedling and podding/maturity stages were characterised and compared.Three QTL were detected for seedling resistance (LG1 and LG9) and a further three were detected for pod/maturity resistance (LG1, LG4 and LG5). Together, these accounted for $34 \%$ and $61 \%$ of the total estimated phenotypic variation, respectively and demonstrated that resistance at the different growth stages is potentially conditioned by different genomic regions. Several of the closest flanking markers may be useful for MAS and for the future pyramiding of potentially different resistance genes into elite backgrounds that are resistant throughout the cropping season.

Key words: ascochyta blight, EST-SSR/SSR, lentil, linkage map, Medicago truncatula, QTL 


\section{Introduction}

Lentil (Lens culinaris Medikus subsp. culinaris) is an important cool-season annual food legume crop grown from the Near East to the Mediterranean area, and in Asia, Europe, USA, Canada and Australia. The world lentil production was 1.86 million tonnes (Mt) during 2008-2009 (Market Outlook Report, 2010). India ranks first in lentil production and consumption, whereas Canada and Turkey are the world's largest lentil exporters.

A major constraint affecting lentil production is the incidence of diseases and especially ascochyta blight, caused by the ascomycete Ascochyta lentis, a serious fungal disease affecting all lentil growing regions of the world. Seedling infection causes stem girdling and plant death, whereas infection at podding and maturity affects seed quality and finally yield (Morrall and Sheppard 1981).The most effective and economical way to manage this disease is to cultivate sustainably resistant cultivars, a major aim of many breeding programs.

Resistance is reported to be governed by genes with major effects (Ford et al. 1999; Nguyen et al. 2001; Ye et al. 2001; 2002), which can be deployed in combinations as multiple gene barriers (Parlevliet 1993). Ye et al. (2001) reported two recessive genes with additive effect and a single recessive gene control foliar resistance in cvs Indianhead and Laird, respectively. Foliar resistance in cv. Northfield (ILL 5588) was reported to be governed by a single dominant gene (Ford et al. 1999); or by one dominant gene for high resistance and one dominant gene for moderate resistance (Ye et al. 2001). Ali (1995) found that ILL5588 was resistant to both seed and foliar infection. These studies suggested that major genes are involved in resistance, however, different levels of resistance at different growth stages have been reported, which may affect the sustainability of the resistance trait throughout the growing season. For example, seedling resistance in Laird was reported to break down during the late podding stage (Gossen and Morrall1983), Pedersen and Morrall (1994) also reported difference in disease severity among seedling and podding stage. To aid in determining if the resistance 
mechanisms at different growth stages within the same genotype are conserved or different, a trait mapping approach is appropriate. Locating the position of major quantitative resistance effects using genome linkage mapping would also enable the potential to pyramid multiple different resistance genes into one superior agronomic background. The use of molecular markers linked to the major different resistance quantitative trait loci (QTL) would improve efficiency and speed of conventional resistance breeding strategies.

In order to identify molecular markers significantly associated with resistance to $A$. lentis, several genomic maps have been developed (Havey and Muehlbauer 1989; Eujayl et al. 1998; Rubeena et al. 2003; Hamwieh et al. 2005; Tullu et al. 2008; Tanyolac et al. 2010). Although several major genomic regions controlling seedling resistance to $A$. lentis have been reported (Ford et al. 1999; Chowdhury et al. 2001; Ye et al. 2001; 2002; Rubeena et al. 2003), those governing resistance at the podding/maturity stage have not been identified. Also, the majority of genome maps were created with mostly arbitrary and dominant RAPD, AFLP and ISSR markers (Eujayl et al. 1997; 1998; Rubeena et al. 2003; Duran et al. 2004; Hamwieh et al. 2005). Nevertheless, the first generation maps served as foundations upon which to build denser maps with greater ultimate application.

A relatively saturated linkage map is required so that a QTL mapping approach can be employed to help determine if separate or common genomic location(s) condition $A$. lentis resistance in the same genomic background at the different crucial developmental stages of seedling and maturity/podding.Once the major QTL have been uncovered, tightly linked markers may be validated for use in marker assisted selection and potentially even as a starting point for the positional cloning of the underlying functional resistance gene(s) (Haley and Andersson 1997). In recent years, considerable progress has been made for positional cloning of several QTL in major crops (Salvi et al 2002; Lui et al. 2008; Fu et al. 2009), however, in legumes most of the positional cloning work has been done with Medicago truncatula and Japonica lotus where several genetic loci responsible for 
symbiosis have been characterized (Stracke et al. 2002; Ane et al. 2004; Zhang et al. 2010).

The number of characterised lentil-specific and co-dominant markers is relatively low and the dearth of lentil-specific genomic information has meant that resources from related species have been used. The potential to transfer genome sequences from the model temperate legume Medicago trucatula to lentil, with clear evidence of conserved genome orders, was demonstrated by Phan et al. (2007). In particular, intron-targeted amplified polymorphic (ITAP) markers were used together with SSR markers to produce a comprehensive lentil genome map. The map was produced using cv. Northfield $x \mathrm{cv}$. Digger $F_{5}$ RIL and other dominant and co-dominant markers. However, this map remains incomplete with marker intervals $>25 \mathrm{cM}$ and larger than $2 \mathrm{n}=14$ representative chromosomal linkage groups. Transfer of EST-SSR/SSR markers from $M$. truncatula would provide further saturation and with markers of functional association since their transferability relies on conservation in the exon regions.

EST-associated and sole SSR primer sequences have been identified from the international genomic sequencing program for $M$. truncatula, for which the transcript database contains more than 230,000 EST (http://www.medicago.org/genome/). Therefore, the aims of the study were to 1) enrich the current map (Phan et al. 2007) through transfer of $M$. trunculata (Mt)originating EST-SSR and sole SSR sequences; 2) identify the genome locations of the major QTL conditioning both seedling and maturity/podding resistance and 3) identify markers close and flanking the individual QTL that could be used for future validation for the pyramiding of differential genes/QTL towards sustainable resistance.

\section{Materials and Methods}

\section{Plant and fungal materials and bioassays}

The RIL population of $94 \mathrm{~F}_{5}$ individuals, developed from a cross of $\mathrm{cv}$. Northfield (ILL 5588, resistant) x cv. Digger (ILL 5722, susceptible), and the parental seed 
were provided by Dr Michael Materne of the Victorian Department of Primary Industries (VicDPI), Horsham, Victoria, Australia.

The Ascochyta lentis AL4 isolate was originally sourced from the VicDPI Horsham disease nursery in 1996, stored freeze dried and passaged through the susceptible host genotype ILL6002 prior to use. For disease bioassays, parental and $F_{5}$ RIL seedlings were raised in $20 \mathrm{~cm}$ diameter pots. These were sown at a density of five plants/pot per RIL or parental genotype with a single replication per bioassay of each RIL and triplicate pots per bioassay of each parent. All plants were raised in a growth room maintained at. $20 \pm 2^{\circ} \mathrm{C}$ with a $16 \mathrm{hr}$ day length.

Seedling bioassays were conducted and disease score data was collected on a 1-9 scale as previously described (Ford et al. 1997) at 14, 21 and 28 days after inoculation (DAl). For maturity/podding stage bioassays, All plants were inoculated ( $A$. lentis or water) using a hand pump until run-off and pots were covered with sealed plastic sheets to maintain humidity and left in the dark for 48 hours to induce optimal spore germination and infection. Then, the plastic sheets were removed and plants were left to grow under artificial epiphytotic conditions. At 14, 21 and 28 DAl the tagged pods were assessed for percentage of total pod infection (Moore et al. 2002).

Genomic DNA extraction, PCR and transferability of SSR primers from Medicago truncatula

Total genomic DNA was extracted from approximately $200 \mathrm{mg}$ of young leaf tissue of each individual using the CTAB method described in Ford et al. (1997). Genomic DNA was quantified with a spectrophotometer and the quality was assessed on agarose gel $(1.8 \%)$, stained with ethidium bromide and visualised under uv-light. DNA was diluted to a working concentration of $20 \mathrm{ng} / \mu \mathrm{l}$ for PCR analysis.

To saturate the existing linkage map, ten EST-SSR primer pairs from Eujayl et al. (2004) and 90 EST-SSR/SSR primer pairs from the Medicago truncatula sequencing project (http://www.medicago.org/genome/genetic map table.html) were used. Of the $100 \mathrm{M}$. truncatula primer pairs, 46 were EST-derived SSR and 54 were sole SSR sequences, these were screened for their transferability and 
amplification in cv. Northfield. Primer pairs that amplified a clear and reproducible product were then assessed for size polymorphism among the parental accessions and across the entire RIL mapping population.

The PCR reaction ( $25 \mu \mathrm{l}$ volume) was conducted in a MyCycler Personal Thermal Cycler (Bio-Rad, Australia) and consisted of PCR buffer (Scientifix, Australia), 3mM $\mathrm{MgCl}_{2}$ (Scientifix, Australia), $0.24 \mathrm{mM}$ of each dNTP (Scientifix, Australia), $0.24 \mu \mathrm{M}$ of each primer (Sigma, Australia), 0.5 units of Taq polymerase (Scientifix, Australia) and $20 \mathrm{ng}$ of template DNA. The PCR conditions were as follows: Initial denaturation at $94{ }^{\circ} \mathrm{C}$ for $5 \mathrm{~min}$, followed by 39 cycles at $94{ }^{\circ} \mathrm{C}$ for $15 \mathrm{~s}$, annealing at $50-62{ }^{\circ} \mathrm{C}$ for $30 \mathrm{~s}$ (dependant on the primer Tm), extension at $72{ }^{\circ} \mathrm{C}$ for $30 \mathrm{~s}$ and final extension at $72{ }^{\circ} \mathrm{C}$ for $5 \mathrm{~min}$. Amplification products were resolved on $2 \%$ agarose or Metaphor (2.5\%) gel and visualised against known molecular weight standards (Lambda DNA - Hind III digested, Invitrogen, Australia) as described above.

\section{Construction of genetic map}

Segregating markers were scored as co-dominant or dominant and the data were added to the existing dataset and used to construct a revised cv. Northfield x cv. Digger genome map. Locus and allele-specific marker data were supplied for the existing map that was produced using the same RIL and parental genomes (Phan et al. 2007). The final map comprised four types of molecular markers; ISSR, RAPD, SSR and ITAP markers. Goodness-of-fit to the expected 1:1 segregation ratio for marker segregation within an RIL population was tested by $X^{2}$ analysis $(P<$ 0.05) and the map was constructed using Map Manager QTX (Manly et al. 2001). For this, markers were assigned to linkage groups using the 'make linkage groups' command at a LOD score of 3.0 and a maximum recombination fraction $(\theta)$ of 0.5 . Kosambi's function was applied to convert recombination percentages to centi Morgan (cM) map unit distance units (Kosambi 1944).

\section{Marker nomenclature}


In the existing map, markers were named as follows: RAPD - capital letter with two digit number; ISSR - 'UBC' with three digit number, SSR - 'ILM' with two digit number; lentil SSRs - 'SSR' with two and three digit number for those developed by Hamwieh et al. (2005) and ITAP - the name as previously presented in Phan et al. (2007). The 21 newly mapped EST-SSR/SSR markers from $M$. truncatula were named using their original names with the last three digits only. Primer pairs with more than one marker size were named by the primer name with a lower case letter $(\mathrm{a}, \mathrm{b}$ or $\mathrm{c})$.

\section{QTL analysis}

No prior assumptions of phenotypic classes were made regarding the raw disease scores of the $F_{5}$ RIL and parents at 14, 21 and 28 DAl. Initially, single point analysis was performed on all markers using the 'Links Report' command to determine any markers significantly associated with the resistance traits $(p<0.05)$. Subsequently, simple interval mapping was conducted to detect QTL effects within marker intervals with a likelihood of odds ratio of 3.0, and without controlling for the effects of other/background QTL. Empirical determination of experiment-wise error rates was performed with 1000 permutation tests to provide a $95 \%$ confidence on the location of QTL within marker intervals (Churchill and Doerge 1994). The effect at each marker locus was estimated by calculating the difference between the total trait variance and the residual variance, expressed as a percentage of the total variance, and was used to estimate the percentage of phenotypic variation explained. Multiple QTL peaks detected within $10 \mathrm{cM}$ regions were regarded as a single QTL.

\section{Results}

\section{SSR marker transferability and map revision}

Three of the 10EST-SSR primer pairs from Eujayl et al. (2004), and 88 (35 ESTSSR and 53 sole SSR) of the 90 primer pairs obtained from the M. truncatula sequencing project amplified a clear and reproducible product of the approximate expected size in cv. Northfield. However, only three of the 38 EST-SSR markers 
(7.9\%) and 14 from 53 SSR markers (26.4\%) were polymorphic among the parental genomes (Table 1). From these, 21 clear and reproducible markers were produced for addition to the existing linkage map (Table 2).

Table 1. Summary of usefulness of $M$. truncatula EST-SSR/SSR markers used for the saturation of the existing lentil linkage map (cv. Northfield x cv. Digger).

\begin{tabular}{llllll}
\hline $\begin{array}{l}\text { Marker } \\
\text { type }\end{array}$ & $\begin{array}{l}\text { No. of } \\
\text { primers } \\
\text { screened }\end{array}$ & $\begin{array}{l}\text { No. of primers } \\
\text { showing } \\
\text { transferability }\end{array}$ & $\begin{array}{l}\text { No. of } \\
\text { polymorphic } \\
\text { primers }\end{array}$ & $\begin{array}{l}\text { No. of } \\
\text { polymorphic } \\
\text { Markers }\end{array}$ & $\begin{array}{l}\text { No. of } \\
\text { mapped } \\
\text { markers }\end{array}$ \\
\hline $\begin{array}{lllll}\text { EST- } \\
\text { SSRs }\end{array}$ & 46 & 38 & $3(7.9 \%)$ & $\begin{array}{l}3(1 \\
\text { marker/primer })\end{array}$ & $3(100 \%)$ \\
SSRs & 54 & 53 & $14(26.4 \%)$ & $\begin{array}{l}18(1.3 \\
\text { markers/primer })\end{array}$ & $12(66.7 \%)$ \\
& & & & & 15 \\
Total & 100 & 91 & 17 & 21 & 15 \\
\end{tabular}

Table 2: List of polymorphic primers between parents cv. Northfield and cv. Digger

\begin{tabular}{|c|c|c|c|c|c|c|}
\hline $\begin{array}{l}\text { S. } \\
\text { No. }\end{array}$ & $\begin{array}{l}\text { Primer } \\
\text { Name }\end{array}$ & $\begin{array}{l}\text { Type of } \\
\text { marker }\end{array}$ & $\begin{array}{l}\text { Forward primer } \\
\text { sequence }\end{array}$ & $\begin{array}{l}\text { Reverse primer } \\
\text { Sequence }\end{array}$ & $\begin{array}{l}\text { Expected } \\
\text { band Size }\end{array}$ & $\begin{array}{l}\text { Annealing } \\
\text { temperature }\end{array}$ \\
\hline 1 & BE325495 & $\begin{array}{l}\text { EST- } \\
\text { SSR }\end{array}$ & $\begin{array}{l}\text { CAGCCACATTTTG } \\
\text { CTGTAAAGA }\end{array}$ & $\begin{array}{l}\text { AGTAACCTTTGA } \\
\text { CCCCAGCAT }\end{array}$ & $300-330$ & 50.2 \\
\hline 2 & ВЕ323614 & $\begin{array}{l}\text { EST- } \\
\text { SSR }\end{array}$ & $\begin{array}{l}\text { GCACCAGGAATAA } \\
\text { TCCAATAACA }\end{array}$ & $\begin{array}{l}\text { AGCCGTCCAGTA } \\
\text { CCTTTGAC }\end{array}$ & 350 & 58.0 \\
\hline 3 & TC16680 & $\begin{array}{l}\text { EST- } \\
\text { SSR }\end{array}$ & $\begin{array}{l}\text { TGGAGCCATCAGA } \\
\text { ATTCCTC }\end{array}$ & $\begin{array}{l}\text { ATTACGATCCAC } \\
\text { CAGGCAAC }\end{array}$ & 75 & 50.2 \\
\hline 4 & AC123571 & SSR & $\begin{array}{l}\text { CTGATCCTTTCCA } \\
\text { AGAAGCG }\end{array}$ & $\begin{array}{l}\text { CGCTAATTGCTG } \\
\text { GCTTCAAA }\end{array}$ & 190 & 56 \\
\hline 5 & AC139354 & SSR & $\begin{array}{l}\text { TGAGAGAGAGAG } \\
\text { GGCGAGAG }\end{array}$ & $\begin{array}{l}\text { AGGGGCTTTTGC } \\
\text { CTATTGTT }\end{array}$ & 275 & 52.2 \\
\hline
\end{tabular}




\begin{tabular}{|c|c|c|c|c|c|c|}
\hline 6 & AC139748 & SSR & $\begin{array}{l}\text { ATCTGGTAGGAGA } \\
\text { TGGTGCG }\end{array}$ & $\begin{array}{l}\text { ATGCAGAGGGGT } \\
\text { GATTCAAG }\end{array}$ & 150 & 58.0 \\
\hline 7 & AC143341 & SSR & $\begin{array}{l}\text { CACGTGGGATGTC } \\
\text { ACCACTA }\end{array}$ & $\begin{array}{l}\text { GCCTTGCTGCAG } \\
\text { AAGCTATT }\end{array}$ & 400 & 59 \\
\hline 8 & AC146569 & SSR & $\begin{array}{l}\text { GACAAACGTTCAA } \\
\text { TGCCACA }\end{array}$ & $\begin{array}{l}\text { GGCTCCCTCCAC } \\
\text { TTGTAATG }\end{array}$ & 270 & 55.0 \\
\hline 9 & AC146588a & SSR & $\begin{array}{l}\text { GGGTTCTATGCAT } \\
\text { TCTTCGC }\end{array}$ & $\begin{array}{l}\text { ССтСССтСССтС } \\
\text { ТСТСТСТС }\end{array}$ & 410 & 56 \\
\hline 10 & AC146588b & SSR & $\begin{array}{l}\text { GGGTTCTATGCAT } \\
\text { TCTTCGC }\end{array}$ & $\begin{array}{l}\text { ССтСССТСССТС } \\
\text { ТСТСТСТС }\end{array}$ & 800 & 56 \\
\hline 11 & AC146588c & SSR & $\begin{array}{l}\text { GGGTTCTATGCAT } \\
\text { TCTTCGC }\end{array}$ & $\begin{array}{l}\text { ССтСССтСССтС } \\
\text { ТСТСТСТС }\end{array}$ & 850 & 56 \\
\hline 12 & AC148097a & SSR & $\begin{array}{l}\text { TTGGTGCACCGTA } \\
\text { TTTTGAG }\end{array}$ & $\begin{array}{l}\text { CCAGGCATCCTT } \\
\text { TTCTTTTC }\end{array}$ & 700 & 50.2 \\
\hline 13 & AC148097b & SSR & $\begin{array}{l}\text { TTGGTGCACCGTA } \\
\text { TTTTGAG }\end{array}$ & $\begin{array}{l}\text { CCAGGCATCCTT } \\
\text { TTCTTTTC }\end{array}$ & $200-220$ & 50.2 \\
\hline 14 & AC149127a & SSR & $\begin{array}{l}\text { GGCTGATTTGAAA } \\
\text { CATGCCA }\end{array}$ & $\begin{array}{l}\text { GGTGGTTGTGGG } \\
\text { ACACTTTT }\end{array}$ & 330 & 55.0 \\
\hline 15 & AC149127b & SSR & $\begin{array}{l}\text { GGCTGATTTGAAA } \\
\text { CATGCCA }\end{array}$ & $\begin{array}{l}\text { GGTGGTTGTGGG } \\
\text { ACACTTTT }\end{array}$ & 100 & 55.0 \\
\hline 16 & AC149208 & SSR & $\begin{array}{l}\text { GTTACACCTAGCC } \\
\text { CCATCCA }\end{array}$ & $\begin{array}{l}\text { CACCAGAGTTAT } \\
\text { GCCAGGGT }\end{array}$ & 175 & 56.0 \\
\hline 17 & AC153128 & SSR & $\begin{array}{l}\text { GTTCCAAAAACGC } \\
\text { ACCAAGT }\end{array}$ & $\begin{array}{l}\text { CATGACAGCAGT } \\
\text { ACATTGCC }\end{array}$ & 550 & 55.0 \\
\hline 18 & AC152551 & SSR & $\begin{array}{l}\text { TCAGCTTCATCAG } \\
\text { CCAAAGA }\end{array}$ & $\begin{array}{l}\text { CCAAACAGGGCC } \\
\text { ATAGACTC }\end{array}$ & 220 & 52.2 \\
\hline 19 & AC157537 & SSR & $\begin{array}{l}\text { GCGTGGGATCAC } \\
\text { GTACTTC }\end{array}$ & $\begin{array}{l}\text { CTCATCCATTGAT } \\
\text { CTTTCCG }\end{array}$ & $500-525$ & 50 \\
\hline 20 & CR538722 & SSR & $\begin{array}{l}\text { GGGTTTGTTGGTA } \\
\text { GTCGGTT }\end{array}$ & $\begin{array}{l}\text { TCGAAAAGATGG } \\
\text { GTGGAGTC }\end{array}$ & 950 & 52.1 \\
\hline 21 & AC168149 & SSR & $\begin{array}{l}\text { GGCTGATTTGAAA } \\
\text { CATGCCA }\end{array}$ & $\begin{array}{l}\text { GGTGGTTGTGGG } \\
\text { ACACTTTT }\end{array}$ & 475 & 52.1 \\
\hline
\end{tabular}

In total,196 polymorphic markers were linked within the revised genome map (cv. Northfield x cv. Digger), comprising 68 ISSR, 21 RAPD, 71 ITAP and 21 SSR 
markers from the previously published map and 15 new Mt EST-SSR/SSR derived markers. However, 6 of 21 EST-SSR/SSR markers remained unlinked. The 11 linkage groups (LG) varied in length from $359.4 \mathrm{cM}$ to $2.4 \mathrm{cM}$ and covered a total of $1392.5 \mathrm{cM}$ with an average marker density of $7.1 \mathrm{cM}$. The EST-SSR/SSR markers from M. truncatula were placed on LG1, LG3, LG5, LG6 and LG7 (Table 3).

Table3. Characteristics of the revised genetic linkage map (cv Northfield x cv Digger)

\begin{tabular}{llll}
\hline Linkage groups & $\begin{array}{l}\text { No of } \\
\text { Markers }\end{array}$ & Length $(\mathrm{cM})$ & $\begin{array}{l}\text { EST-SSR/SSR Marker } \\
\text { from M. truncatula /LG }\end{array}$ \\
\hline LG1 & 27 & 208.9 & 2 \\
LG2 & 37 & 188.4 & None \\
LG3 & 47 & 359.4 & 4 \\
LG4 & 22 & 158.9 & None \\
LG5 & 17 & 146.4 & 5 \\
LG6 & 12 & 103.6 & 2 \\
LG7 & 14 & 117.6 & 2 \\
LG8 & 4 & 16.5 & None \\
LG9 & 8 & 54 & None \\
LG10 & 2 & 2.4 & None \\
LG11 & 6 & 36.4 & None \\
Total & 196 & 1392.5 & 15 \\
\hline
\end{tabular}

The addition of new markers to the existing linkage map caused several rearrangements in map order and linkage group size. For example, LG3 was increased from $187.3 \mathrm{cM}$ (37 markers) to $359.4 \mathrm{cM}$ (47 markers) and LG11 was reduced from $137.7 \mathrm{cM}$ (13 markers) to $36.4 \mathrm{cM}$ (6 markers).

\section{Segregation distortion}

The inheritance of most of the markers fitted a 1:1 segregation ratio $(P<0.05)$. However, five of the 21 EST-SSR/SSR markers (AC146588b, AC139354, 
AC148097a, AC148097b and BE323614) from $M$. tuncatula showed distorted segregation from the expected Mendelian ratio for RIL $F_{5}$ progeny $(1: 1)(P<0.05)$ (Table 4). The segregation distortion did not correlate with the number of unlinked markers as none of the unlinked marker showed distorted segregation. All of the distorted markers were mapped and concentrated in LG1, LG3, LG5 and LG6. Table 4: Segregation distortion and unlinked markers on lentil linkage map (cv. Digger x cv. Northfield) from M. truncatula markers

\begin{tabular}{llll}
\hline $\begin{array}{l}\text { Marker } \\
\text { type }\end{array}$ & $\begin{array}{l}\text { No. of } \\
\text { markers }\end{array}$ & $\begin{array}{l}\text { Distorted } \\
\text { segregation }\left(x^{2}\right. \\
\text { at } \mathrm{P}<0.05)(\%)\end{array}$ & $\begin{array}{l}\text { Unlinked } \\
\text { markers }\end{array}$ \\
\hline EST-SSR & 3 & 1 & - \\
SSR & 18 & 4 & 6 \\
Total & 21 & 5 & 6 \\
\hline
\end{tabular}

\section{QTL governing resistance to $A$. lentis}

Single point analyses detected up to 22 markers significantly associated with resistance following 14, 21 and 28 DAl of seedling or maturity/pod infection. The majority associated with seedling resistance (10) were located on LG1 and 3 and those associated with pod/maturity resistance were located on LG1, 2, 3, 4 and 5 (Fig. 1). The phenotypic variation explained by individual markerswas from $3 \%$ to $6 \%$ (seedling) and from $3 \%$ to $8 \%$ (pod/maturity). None of the 19 markers for seedling resistance was consistently associated across all three scoring periods, indicating that potentially different resistance mechanisms may operate at different DAI. However, seven markers were commonly associated with seedling resistance at 21 and 28 DAl scoring periods. On the other hand, among the markers associated with pod/maturity resistance, 10 were consistent across all of the scoring periods, potentially indicating a more restricted genomic involvement in defence at this later growth stage. One RAPD marker, V14a, was associated with seedling resistance at 21 and $28 \mathrm{DAl}$ as well as pod resistance at all of the scoring periods, which may indicate that the defence gene(s) at this locus are stable among growth stages and disease progress times. 
Simple interval mapping detected six genomic regions associated with seedling and/or pod/maturity resistance. Three conditioning seedling resistance were QTL-1 at 14 DAI, QTL-2 at 21 DAl and 28 DAl and QTL-3 at 14, 21 and 28 DAl (Fig. 1) Together, they accounted for $34 \%$ of the total estimated phenotypic variance. Three different genomic regions were consistently detected for pod/maturity resistance at every scoring period; QTL-4, QTL-5 and QTL-6. Together, they accounted for $61 \%$ of the total estimated phenotypic variance (Table 2). QTL-3 conferring seedling resistance and QTL-4, 5 and 6 conferring resistance at podding/maturity were detected at every scoring period, potentially indicating stable expression of resistance during early to late reproductive stage at this locus. 


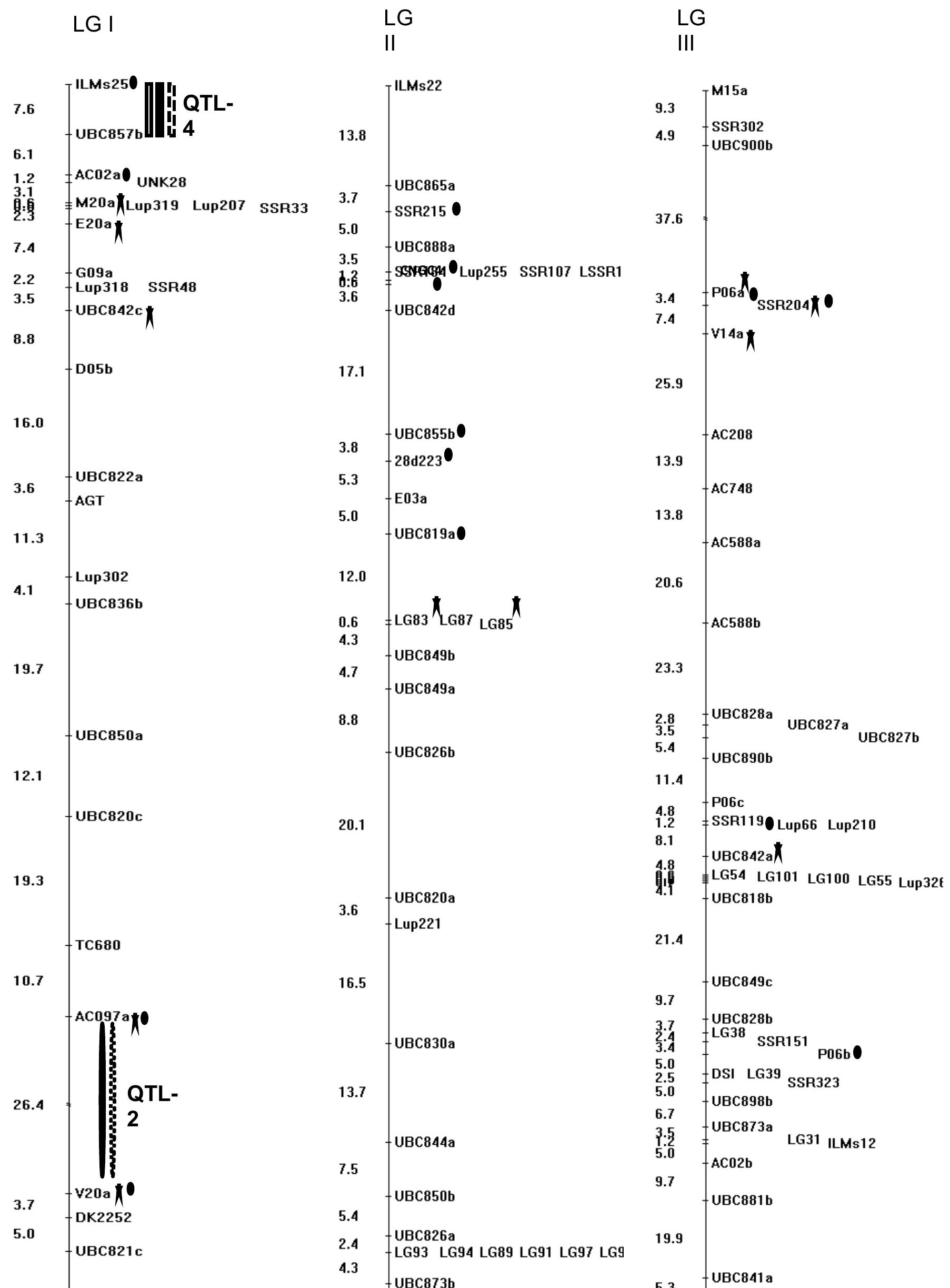



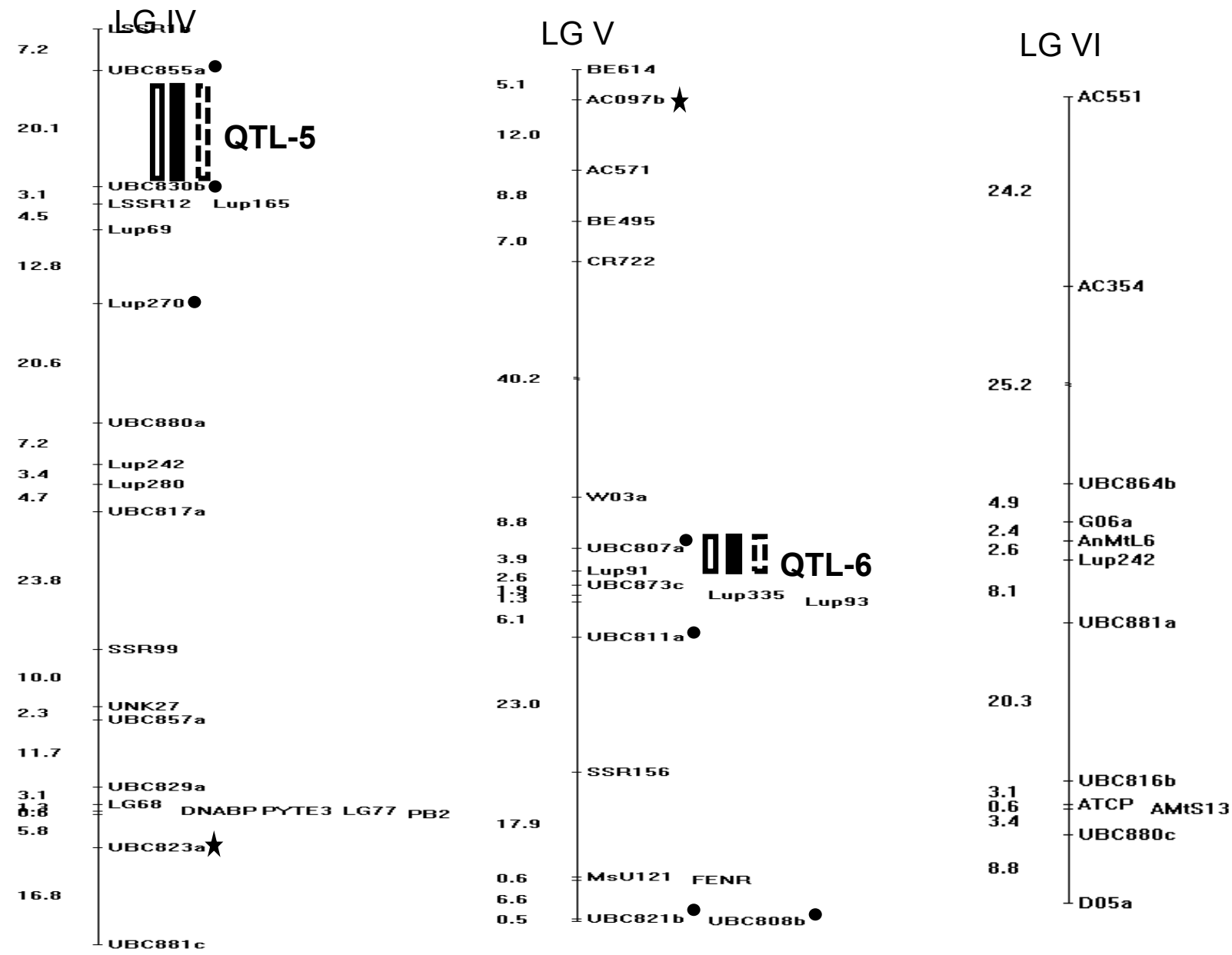

Figure1. Genetic linkage map of the lentil genome (cv. Northfield x cv. Digger) showing locations of putative QTL conditioning ascochyta blight resistance at seedling and $\mathrm{pod} / \mathrm{maturity}$ stage at various scoring periods detected by simple interval mapping.

Stars indicate markers significantly associated with resistance at seedling and dots indicate markers significantly associated with resistance at pod/maturity stage by single point analysis $(P<0.05)$.

All resistance QTL were flanked by one or more significant markers detected by single point analysis. ITAP marker DK 225 was collocated with QTL-1 (at 14 DAI scoring period) and ISSR marker UBC 890a was collocated with QTL-3 at all scoring periods. QTL-2 was flanked by SSR marker AC097a from M. truncatula at $10 \mathrm{cM}$ and RAPD marker V20a at 16cM (at 21 and $28 \mathrm{DAI}$; Table 5). SSR marker 
ILMs 25 was collocated with QTL-4 at all scoring periods. QTL-5 was flanked by ISSR markers, UBC 855a and UBC 830b and UBC 807a was associated with QTL6 at all scoring periods (Table 5 ).

Table 5: Putative QTL for Ascochyta lentis resistance in the cv. Northfield (ILL5588) $x$ cv. Digger (ILL5722) population at two developmental stages (seedling and $\mathrm{pod} / \mathrm{maturity)}$ at 14,21 and $28 \mathrm{DAl}$.

\begin{tabular}{|c|c|c|c|c|c|c|}
\hline $\begin{array}{l}\text { Assessment } \\
\text { period }\end{array}$ & QTL & $\begin{array}{l}\text { Linkage } \\
\text { group }\end{array}$ & $\begin{array}{l}\text { Interval } \\
\text { length } \\
\text { (cM) }\end{array}$ & Flanking markers & $\begin{array}{l}\text { Additive } \\
\text { effect }\end{array}$ & $R^{2}(\%)$ \\
\hline \multicolumn{7}{|c|}{ Seedling stage } \\
\hline \multirow[t]{2}{*}{$14 \mathrm{DAl}$} & QTL 1 & LG1 & 10.3 & DK 225-UBC825c & 0.26 & 6 \\
\hline & QTL 3 & LG9 & 2.3 & UBC890-ARG10 & 0.18 & 3 \\
\hline \multirow[t]{2}{*}{21 DAI } & QTL 2 & LG1 & 26.4 & AC097a-V20a & 0.54 & 8 \\
\hline & QTL 3 & LG9 & 2.3 & UBC890-ARG10 & 0.33 & 6 \\
\hline \multirow[t]{2}{*}{$28 \mathrm{DAl}$} & QTL 2 & LG1 & 26.4 & AC097a-V20a & 0.69 & 7 \\
\hline & QTL 3 & LG9 & 2.3 & UBC890-ARG10 & 0.33 & 4 \\
\hline $\begin{array}{l}\text { Total } \\
\text { variance }\end{array}$ & & & & & & 34 \\
\hline \multicolumn{7}{|c|}{ Pod/maturity stage } \\
\hline \multirow[t]{3}{*}{$14 \mathrm{DAl}$} & QTL 4 & LG1 & 7.6 & ILMs25-UBC857b & 0.50 & 7 \\
\hline & QTL 5 & LG4 & 20.1 & UBC855a-UBC830b & -0.64 & 7 \\
\hline & QTL 6 & LG5 & 3.9 & UBC807a-Lup91 & 0.52 & 7 \\
\hline \multirow[t]{3}{*}{$21 \mathrm{DAl}$} & QTL 4 & LG1 & 7.6 & ILMs25-UBC857b & 0.64 & 8 \\
\hline & QTL 5 & LG4 & 20.1 & UBC855a-UBC830b & -0.76 & 7 \\
\hline & QTL 6 & LG5 & 3.9 & UBC807a-Lup91 & 0.58 & 6 \\
\hline \multirow[t]{3}{*}{$28 \mathrm{DAl}$} & QTL 4 & LG1 & 7.6 & ILMs25-UBC857b & 0.51 & 6 \\
\hline & QTL 5 & LG4 & 20.1 & UBC855a-UBC830b & -0.67 & 7 \\
\hline & QTL 6 & LG5 & 3.9 & UBC807a-Lup91 & 0.52 & 6 \\
\hline Total & & & & & & 61 \\
\hline
\end{tabular}


variance

\section{Discussion}

The existing lentil linkage map (Phan et al. 2007) was enhanced with the addition of EST-SSRs/ SSRs from M. truancatula and the comparative location(s) of QTL governing seedling or pod/maturity resistance to A. lentis was determined. Among the 100 EST-SSR and SSR markers tested for transferability to lentil from $M$. truncatula, many that were transferred were SSR sequences associated with EST. This is not surprising since EST-SSR markers are derived from transcribed genomic regions and hence are expected to be conserved (Scott et al. 2000). Ultimately, there is potential to associate such gene-specific loci with functionality, particularly since the $M$. trunculata genome is soon to be completely sequenced (Young and Udvardi 2009).

The newly mapped EST-SSR/SSR markers from $M$. truncatula filled marker intervals and formed clusters in the centre or upper central or lower central part of the LG, possibly indicating their association with centromeres. A similar trend of clustering of markers was previously observed in lentil (Eujayl et al. 1998; Rubeena et al.2003; Durán et al. 2004; Hamwieh et al. 2005; Phan et al. 2007) and in the related legume chickpea (Winter et al. 2000). Although the newly mapped markers were genetically linked to the existing mapped markers (Phan et al. 2007) in each LG, suggesting that all previously mapped chromosomes were represented (Paterson 1996), there still remained nine unlinked markers and the number of LG was too many for the haploid chromosomal number of lentil $(n=14)$. A map is considered complete when the number of linkage groups is equal to the haploid chromosome number of the plant species and no unlinked markers are left. Although incomplete, this map was of adequate density to determine locations of genomic loci governing $A$. lentis resistance.

Similar to the previous study by Rubeena et al. (2006), multiple QTL associated with seedling resistance were identified, which was in contrast to the single 
dominant gene identified in Northfield (Ford et al. 1999). Comparison between the population derived from Northfield (ILL5588)/Digger (ILL5722) and ILL5588/ILL7537 from Rubeena et al. (2006) revealed QTL 1 to be in the same genomic region as QTL 5 on LG1 conferring seedling blight resistance, and QTL 5 for pod resistance adjacent to the genomic region of QTL 3 for 21 DAl seedling resistance on LG 4. Two markers, P06a and V14a, were found significantly associated with seedling resistance in both the populations. This comparison helped to validate the seedling resistance in $\mathrm{cv}$. Northfield.

Further validation among different genetic backgrounds is required to determine if these QTL are unique to the ILL5588 genome or represent common resistance loci in lentil. The statistically significant markers that flanked the QTL for seedling (ITAP marker DK 225, M. truncatula SSR marker AC097a, ISSR marker UBC 890a and RAPD marker V20a) and pod blight (SSR marker ILMs 25 and ISSR markers UBC 855a, UBC 830b and UBC 807a) resistance, will provide an opportunity for MAS in blight resistance breeding. These also offer possibility of introduction or pyramiding of these QTL into elite germplasm, to develop improved lentil cultivars.

The QTL for blight resistance accounted for $34 \%$ and $61 \%$ of the total estimated phenotypic variance at seedling and podding stage, respectively. The remaining and unaccounted variance may be due to the possible involvement of additional unidentified loci, which have not been detected either because of incomplete genome coverage or the small RIL population size as well as experimental and environmental variation.

Different QTL contributed towards seedling resistance at 14 DAI and common QTL were present at 21 and 28 DAl. However, the presence of three QTL was consistent at different DAl for pod resistance, exhibiting the involvement of relatively few genomic regions for resistance at maturity. This can be explained with the view that the pod stage was almost senescent, so potentially lower numbers of active defence genes would have been expected and hence potentially fewer differences in genomic regions involved in defence at this stage.

Phenotypic analysis of recombinants carrying different combinations of the resistance QTL is required to determine potential additive effects that may help to 
slow down the rate of disease development which will reduce the area under the disease progress curve (AUDPC). This will eventually provide greater sustainability of resistance, also given that the $A$. lentis population is heterothallic and hence diverse (Galloway et al. 2004). The development of such elite lentil cultivars with combinations of QTL for seedling and pod resistance will contribute substantially to the management of this disease and help reduce losses.

In conclusion, this study has provided insight towards transfer and integration of EST-SSR/SSR markers from $M$. truncatula into the lentil linkage map. The newly mapped EST-SSR/SSR markers filled the marker interval gaps on several of the previously identified LG. This map will also be useful in the future location of gene loci governing desirable traits. This will lead to the selection and pyramiding of different resistance gene combinations and result in more durably resistant cultivars. Furthermore, markers that flank the gene(s) could be used in markerassisted selection, potentially reducing the time for breeding for improved varieties.

\section{Acknowledgement:}

We wish to thank Bioversity International, Rome for awarding the Vavilov-Frankel Fellowship to the first author to support this work at the University of Melbourne. We are grateful to Dr Michael Materne of the Victorian Department of Primary Industries (VicDPI), Horsham, Victoria, Australia for providing seed and breeding advice.

\section{References:}

Ali S.M. 1995. Register of Australian grain legume cultivars. Lens culinaris (lentil) cv. Northfield. Aust J Exp Agr 35: 181-1182.

Chowdhury M.A., Andrahennadi C.P., Slinkard A.E. and Vandenberg A. 2001. RAPD and SCAR markers for resistance to Ascochyta blight in lentil. Euphytica 118: 331-337. 
Churchill G.A. and Doerge R.W. 1994. Empirical threshold values for quantitative trait mapping. Genetics 18: 963-971.

Durán Y., Fratini R., García P. and Pérez M. 2004. An intersubspecific genetic map of Lens. Theor Appl Genet 108: 1265-1273.

Eujayl I, Sledge M.K., Wang L., Chekhovskiy K., Zwonitzer J.C. and Mian M.A.R. 2004. Medicago truncatula EST-SSRs reveal cross-species genetic markers for Medicago ssp. Theor Appl Genet 108: 414-422.

Eujayl I., Baum M., Erskine W., Pehu E. and Muehlbauer F.J. 1997. The use of RAPD markers for lentil genetic and the evaluation of distorted $F_{2}$ segregation. Euphytica 96:405-412.

Eujayl I., Baum M., Powell W., Erskine W. and Pehu E. 1998. A genetic linkage map of lentil (Lens sp.) based on RAPD and AFLP markers using recombinant inbred lines. Theor Appl Genet 97:83-89.

Ford R., Pang E.C.K. and Taylor P.W.J. 1997. Diversity analysis and species identification in Lens using PCR generated markers. Euphytica 96:247-255.

Ford R., Pang E.C.K. and Taylor P.W.J. 1999. Genetics of resistance to ascochyta blight of lentil and the identification of closely linked markers. Theor Appl Genet 98:93-98.

Fu D., Uauy C., Distelfeld A., Blechl A., Epstein L., Chen X., Sela H., Fahima T., and Dubcovsky J. 2009. A kinase-START gene confers temperaturedependent resistance to wheat stripe rust. Science 323:1357-1360.

Galloway J., MacLeod W.J. and Lindbeck K.D. 2004. Formation of Didymellalentis, the teleomorph of Ascochyta lentis, on lentil stubble in the field in Victoria and Western Australia. Australas Plant Path 33: 449-450.

Gossen B.D. and Morrall R.A.A. 1983. Effect of ascochyta blight on seed yield and quality of lentil. Can J Plant Pathol 5:168-173.

Haley C.A. and Andersson L. 1997. Linkage mapping of quantitative trait loci in plants and animals. In: Dear P. H. (ed.), Genome Mapping - A Practical Approach. Oxford University Press, New York, Pp. 49-71.

Hamwieh A., Udupa S.M., Choumane W., Sarker A., Dreyer F., Jung C. and Baum M. 2005. A genetic linkage map of Lens sp. based on microsatellite 
and AFLP markers and the localization of Fusarium vascular wilt resistance. Theor Appl Genet 110:669-677.

Havey M.H. and Muehlbauer F.J. 1989. Linkages between restriction fragment length, isozyme and morphological markers in lentil. Theor Appl Genet 77: 395-401.

Kosambi D.D. 1944. The estimation of map distances from recombination values. Anls Eug 12:172-175.

Liu S., Pumphrey M.O., Gill B.S., Trick H.N., Zhang J.X., Dolezel J., Chalhoub B. and Anderson J. A. 2008. Toward positional cloning of Fhb1, a major QTL for Fusarium head blight resistance in wheat. Cereal Res Commun 36:195-201.

Manly K.F., Cudmore R.H. Jr. and Meer J.M. 2001. Map Manager QTX, cross-platform software for genetic mapping. Genome 12: 930-932.

Market Outlook Report (2010). Lentils: Situation and Outlook. www.agr.gc.ca. Moore K., Knights T., MacLead B., Kimber R., Bretag T., Fulbohm M. and Slatter J. 2002. Pulse Australia National Chickpea Disease Rating System for Extension Workers. GRDC - Research Updates.

Morrall R.A.A. and Sheppard J.W. 1981. Ascochyta blight on lentils in western Canada: 1978-1980. Can Plant Dis Surv 61: 7-12.

Nguyen T.T., Taylor P.W.J., Brouwer J.B., Pang E.C.K. and Ford R. 2001. A novel source of resistance in lentil (Lens culinaris ssp. culinaris) to ascochyta blight caused by Ascochyta lentis. Aust Plant Pathol 30: 211-215.

Parlevliet, J.E. 1993. What is durable resistance, a general outline. In: Jacobs T. and Parlevliet J. E. (eds), Durability of Disease Resistance. Kluwer, Dordrecht, Pp. 23-29.

Paterson A.H. 1996. Making genetic maps. In: Paterson A.H. (Ed.), Genome Mapping in Plants. Landes RG Company, San Diego, California, Acad Press, Austin, Texas, Pp. 23-39.

Pedersen E.A. and Morrall R.A.A. 1994. Effects of cultivar, leaf wetness duration, temperature, and growth stage on infection and development of ascochyta blight on lentil. Phytopathology 84:1024-1030. 
Phan H.T., Ellwood S.R., Hane J.K., Ford R., Materne M. and Oliver R.P. 2007. Extensive microsynteny between Medicago truncatula and Lens culinaris ssp. culinaris. Theor Appl Genet 114:549-558.

Rubeena, Ford R. and Taylor P.W.J. 2003. Construction of an intraspecific linkage map of lentil (L. culinaris ssp. culinaris). Theor Appl Genet 107: 910916.

Rubeena, Taylor P.W.J., Ades P.K. and Ford R. 2006. QTL mapping of resistance in lentil (Lens culinaris ssp. culinaris) to ascochyta blight (Ascochyta lentis). Plant Breed 125:506-512.

Salvi S., Tuberosa R., Chiapparino E., Maccaferri M., Veillet S., van Beuningen L., Isaac P., Edwards K. and Phillips R.L. 2002. Toward positional cloning of Vgt1, a QTL controlling the transition from the vegetative to the reproductive phase in maize. Plant Mol Biol 48:601-613.

Scott K.D., Eggler P., Seaton G., Rossetto M., Ablett E.M., Lee L.S. and Henry R.J. 2000. Analysis of SSRs derived from grape ESTs. Theor Appl Genet 100:723-726.

Stracke S., Kistner C., Yoshida S., Mulder L., Sato S., Kaneko T., Tabata S., Sandal N., Stougaard J., Szczyglowski K. and Parniske M. 2002. A plant receptor-like kinase required for both bacterial and fungal symbiosis. Nature 417:959.

Tanyolac B., Ozatay S., Kahraman A. and Muehlbauer F.J. 2010. Linkage mapping of lentil (Lens culinaris L.) genome using recombinant inbred lines revealed by AFLP, ISSR, RAPD and some morphologic markers. J Agric Biotech Sustainable Dev 2:001-006.

Tullu A., Tar'an B., Warkentin T. and Vandenberg A. 2008. Construction of an intraspecific linkage map and QTL analysis for earliness and plant height in lentil. Crop Sci 48: 2254-2264.

Winter P., Benko-Iseppon A.M., Hüttel B., Ratnaparkhe M., Tullu A., Sonnante G., Pfaff T., Tekeoglu M., Santra D., Sant V.J., Rajesh P.N., Kahl G. and Muehlbauer F.J. 2000. A linkage map of the chickpea (Cicer arietinum L) genome based on recombinant inbred lines from a $C$. arietinum $\times C$. 
reticulatum cross: localization of resistance gene for fusarium wilt races 4 and 5. Theor Appl Genet 101:1155-1163.

Ye G., McNeil D.L. and Hill G.D. 2002. Breeding for resistance to lentil ascochyta blight. Plant Breed 121: 185-191.

Ye G., McNeil D.L. and Hill G.D. 2001. Inheritance of resistance to ascochyta blight in lentil. N Z Plant Prot 54: 198-201.

Young N.D. and Udvardi M. 2009. Translating Medicago truncatula genomics to crop legumes. Curr Opin Plant Biol 12:193-201.

Zhang Q., Blaylock L.A. and Harrison M.J. 2010. Two Medicago truncatula half-ABC transporters are essential for arbuscule development in arbuscular mycorrhizal symbiosis. Plant Cell 22:1483-1497. 